\title{
Anna Lebet-Minakowska*
}

\section{Szymon Rabinowicz - odnaleziony}

Muzeum Narodowe w Krakowie posiada w swoich zbiorach najciekawszą w Polsce kolekcję żydowskiego rzemiosła artystycznego. Dla muzealnika ma ona szczególną wartość z jeszcze jednego względu: prawie w całości została skompletowana w latach 1935-1939, wiele zabytków ma ustaloną proweniencję i źródło nabycia, w znacznej mierze znane są nawet kwoty, za które zakupiono poszczególne obiekty. Większość muzeów w Polsce posiadających zbiory rzemiosła żydowskiego nie zna ich pochodzenia - zazwyczaj są to zabytki, które trafiły do zbiorów przypadkowo, najczęściej w okresie powojennym, a ich wartość artystyczna bywa niewielka. Muzeum Narodowe w Krakowie było przed II wojną światową jedynym, które celowo kupowało i kolekcjonowało arcydzieła rzemiosła żydowskiego. Ważnym źródłem do badania proweniencji wspomnianej kolekcji są zachowane w Archiwum Muzeum Narodowego w Krakowie i Archiwum Narodowym w Krakowie dokumenty dotyczące pochodzenia kolekcji oraz osób, od których zabytki kupowano.

Odnalezienie w Archiwum Muzeum Narodowego w Krakowie niewielkiej koperty z napisem: „Tajne, może otworzyć tylko dyrektor Muzeum Narodowego" rzuciło całkiem nowe światło na pochodzenie kolekcji. W kopercie znajduje się odpis protokołu z posiedzenia, które odbyło się w dniu 15 stycznia 1935 r. w gabinecie Władysława Zawistowskiego, naczelnika Wydziału Sztuki Ministerstwa Wyznań Religijnych i Oświecenia Publicznego. Na spotkaniu, w którym uczestniczyli m.in. dyrektor Muzeum Narodowego w Krakowie Feliks Kopera i Główny Konserwator Jerzy

* kustosz kolekcji rzemiosła artystycznego Muzeum Książąt Czartoryskich; autorka licznych publikacji (w tym katalogu judaików ze zbiorów Muzeum Narodowego w Krakowie); członek międzynarodowych organizacji naukowych: World Union of Jewish Students i European Association for Jewish Studies; laureatka nagrody im. Księdza Stanisława Musiała; zainteresowania badawcze: sztuka i rzemiosło Żydów polskich; e-mail: alebet@ mnk.pl 
Remer, zapadła decyzja o przyznaniu specjalnej subwencji na zakup judaików w celu utworzenia odrębnego „działu judaików” - kolekcji rzemiosła żydowskiego w obrębie zbiorów Muzeum Narodowego w Krakowie'. Zawarta w ministerstwie umowa została objęta klauzulą tajności, co wyjaśnia dopisana na dokumencie uwaga F. Kopery: „Sprawa ma być poufną ze względu na nieutrudnianie zakupu przez podnoszenie cen i konkurencję, jako też i z innych powodów. Jest nadzieja, że subwencja ta nie ograniczy się do jednego roku budżetowego, gdy rezultaty okażą się dobre".

Muzeum otrzymało wówczas od ministra obiecaną sumę 10000 zł. Była to znaczna kwota w porównaniu z całkowitym budżetem rocznym na zakup zabytków do zbiorów Muzeum Narodowego w Krakowie, który wynosił 7000 zł. Z otrzymanego grantu szczegółowo rozliczył się dyrektor Kopera w sporządzonym w 1938 r. sprawozdaniu adresowanym do Departamentu Muzeów Ministerstwa Wyznań Religijnych i Oświecenia Publicznego. W sprawozdaniu skrótowo opisane zostały zakupione przedmioty oraz listy zabytków wraz z wyszczególnieniem kwot, jakie zapłacono za poszczególne obiekty lub ich grupy. Do sprawozdania dołączone jest zestawienie rachunków, których odpisy również przechowywane są w archiwum. W zestawieniu, przy poszczególnych obiektach, figurują sumy, za które je nabyto, nazwy miejscowości, z których pochodzą, a na rachunkach nazwiska osób, od których je zakupiono ${ }^{2}$. Poza nazwami powszechnie znanych przedwojennych antykwariatów, dr. Schelberga w Katowicach, Taffeta w Krakowie czy Salzsteina w Warszawie, pojawiają się nazwiska osób zupełnie nieznanych z antykwarycznej działalności. Jednym z najczęściej powtarzających się sprzedających jest Szymon Rabinowicz. Wśród zakupionych od niego przedmiotów trudno wyznaczyć konkretniejsze zespoły zabytków. Najliczniejszą grupę zakupionych w latach 1937-1939 obiektów stanowią tkaniny pochodzące z różnych miejscowości. M.in. wszystkie zakupione wówczas sukienki na Torę i jeden parochet ${ }^{3}$ pochodziły z synagogi w Szumsku koło

${ }^{1}$ Zob. Aneks I.

${ }^{2}$ Archiwum Muzeum Narodowego w Krakowie (dalej: AMNK), Zbiory i zakupy 1935, sygn. L/189c.

${ }^{3}$ Parochet - zasłona na aron (ha-)kodesz. Spełniała jedną z najważniejszych funkcji w synagodze - oddzielała od reszty pomieszczenia szafkę lub wnękę w ścianie, w której przechowywano zwoje Tory. Była podnoszona bądź odsuwana podczas uroczystego nabożeństwa połączonego z czytaniem Tory. Jej pierwowzorem była zasłona w Świątyni Salomona, uszyta według nakazu Boga. 
Krzemieńca ${ }^{4}$, ale w zespole znalazły się też parochety i kaporety ${ }^{5}$ z Borysławia $^{6}$, Łunińca ${ }^{7}$, Sandomierza, Sanoka, Radziejowa ${ }^{8}$ i Włodzimierza Wołyńskiego 9 . Jedna z najciekawszych zasłon na aron (ha)kodesz ${ }^{10}$ zakupiona została w 1937 r., S. Rabinowicz podał jako miejsce jej pochodzenia synagogę w Miziorzycy koło Łukowa ${ }^{11}$. Kolejnym rarytasem wśród zakupionych wówczas judaików jest sziwiti ${ }^{12}$, uszyte $\mathrm{z}$ tkaniny, w formie bogato haftowanej i aplikowanej makaty zawieszanej przed pulpitem kantora, które pochodzi z synagogi w Prużanie ${ }^{13}$. W zakupionym w 1938 r. zespole sukienek na Torę ${ }^{14}$ szczególnie warta uwagi jest jedna, uszyta z XVII-wiecznej

${ }^{4}$ Szumsk koło Krzemieńca w województwie wołyńskim, obecnie Ukraina, przed II wojną światową był centrum życia żydowskiego (Żydzi stanowili blisko 80\% populacji), znajdowała się tam murowana synagoga.

${ }^{5}$ Kaporet - lambrekin zawieszany ponad parochetem.

${ }^{6}$ Borysław koło Drohobycza nad rzeką Tyśmienicą, obecnie Ukraina, obwód lwowski.

${ }^{7}$ Łuniniec koło Brześcia, obecnie Białoruś, stolica rejonu w obwodzie brzeskim.

${ }^{8}$ Nazwa miejscowości niejednoznaczna; prawdopodobnie mowa o miejscowości Radziejowa koło Włocławka, gdzie była znaczna gmina żydowska, ale mogą to być też: Radziejowa koło Wołkowyi, Radziejów koło Lublina lub Radziejowce nad Zaharem na terenie obecnej Ukrainy, Słownik geograficzny Królestwa Polskiego i innych krajów słowiańskich, t. 9, red. Filip Sulimierski, Bronisław Chlebowski, Władysław Walewski, Warszawa 1888, s. 466-467.

${ }_{9}^{9}$ Włodzimierz Wołyński, miasto nad rzeką Ług, obecnie Ukraina, była tam znaczna gmina żydowska i synagoga.

${ }^{10}$ Aron (ha-)kodesz (hebr. arka) - wnęka we wschodniej ścianie synagogi zamykana zazwyczaj dwuskrzydłowymi drzwiami lub szafa, w której przechowuje się zwoje Tory.

${ }^{11} \mathrm{Na}$ mapie Rzeczypospolitej nie widnieje taka miejscowość, dopiero po kilku latach udało mi się ustalić, że osoba wystawiająca rachunek popełniła błąd w zapisie nazwy miejscowości. Zasłona pochodzi z synagogi w Międzyrzeczu koło Łukowa, Anna Le bet-Minakow ska, Parochet - dar „Pobożnej Pani Sary” - jako przykład przekazu symbolicznego, [w:] Żydzi Wschodniej Polski. Seria 5. W kręgu judaizmu, red. Jarosław Ławski i Iwona E. Rusek, Białystok 2017, s. 165-199; Anna Lebet-Minakowska, Katalog judaików, cz. 1: Tkaniny, Kraków 2008, s. 39-41.

${ }^{12}$ Sziwiti (hebr. sziwiti - stawiam) - ozdobna plakieta zawierająca słowa psalmu: „Stawiam sobie Pana zawsze przed oczy" (Ps 16, 8), mianem tym określano zazwyczaj cały przedmiot. Ozdobne tabliczki z tymi słowami umieszcza się przed pulpitem kantora w synagodze.

${ }^{13}$ Prużana koło Brześcia, obecnie miasto na Białorusi położone w obwodzie brzeskim, przed II wojną światową siedziba gminy żydowskiej, A. Lebet-Minakowska, Kata$\log \ldots$, s. $78-79$.

${ }_{14}$ Meil (hebr. meil) - sukienka na Torę, uszyty z tkanin pokrowiec ochraniający zwój Tory. Sukienka (zwana czasem „koszulką”) uszyta bywa z cennych tkanin, często haftowana. 
tkaniny srebrnolitej, z haftowanym złotą nicią na foremkach napisem donacyjnym z 1713 r. ${ }^{15}$ Pokrowiec jest jednym z najstarszych judaików w polskich zbiorach.

Równie interesujący zespół został zakupiony za pośrednictwem S. Rabinowicza 5 września 1938 r. ${ }^{16}$ Składał się z pięciu wskaźników, tzw. jadów ${ }^{17}$, używanych w synagodze jako pomoc przy czytaniu Tory, pochodzących z Dubna ${ }^{18}$ koło Równego, oraz tarcz zawieszanych na zwojach Tory z synagogi w miejscowości Równe ${ }^{19}$. Srebrne i srebrzone tarcze datowane są głównie na koniec XVIII i początek XIX w. Na tym samym rachunku widnieją dwie korony na Torę pochodzące $z$ miejscowości Dubna i Krzemieniec $^{20}$. Jedna z ciekawszych plakiet, z wizerunkiem kosza kwiatów i umieszczonych po obu jego stronach ptaków, podarowana została do synagogi w 1753 r. przez Eliego, syna Judy Lejba, ze słowami błogosławieństwa dla jego syna Fajbusza ${ }^{21}$. Inna tarcza, zdobiona tablicami dekalogu umieszczonego pomiędzy dwoma lwami pod osadzoną nad nimi plastyczną koroną, pochodząca z Równego ${ }^{22}$, ufundowana została w 1811 r. przez bractwo Aszirej Kodesz (bogatych Żydów). Wśród zakupionych od S. Rabinowicza licznych judaików warto także wspomnieć o znacznych rozmiarów miedzianym pojemniku na wodę, zwanym kijor $^{23}$, ofiarowanym przez rabiego Cwi Hirsza do synagogi w Wiśniczu koło Krakowa w 1744 r. Naczynia takie umieszczano przed wejściem do synagogi, służyły do rytualnych ablucji.

15 A. Lebet-Minakowska, Katalog..., s. 81-82.

${ }^{16}$ AMNK, Rachunki, sygn. LII/357.

${ }^{17} \mathrm{Jad}$ (hebr. ręka) - wskaźnik zakończony dłonią z wyciągniętym palcem wskazującym służący do czytania zwojów Tory, których nie wolno było dotykać rękami, spełniał funkcję zastępczą.

${ }_{18}$ Dubno nad Ikwą, miasto koło Równego, obecnie w obwodzie rówieńskim na Ukrainie.

${ }^{19}$ Równe, obecnie miasto w granicach Ukrainy, przed II wojną światową w granicach Rzeczypospolitej, ośrodek życia żydowskiego, znajdowało się tam kilka synagog i kilkadziesiąt domów modlitwy, cmentarz, kahał, chedery i szkoły stopnia średniego, teatr, działały stowarzyszenia i organizacje dobroczynne, partie polityczne i kluby sportowe.

${ }^{20}$ Krzemieniec, obecnie miasto w obwodzie tarnopolskim na Ukrainie, przed II wojną światową siedziba gminy żydowskiej, ośrodek życia religijnego i społecznego, działały tam m.in.: średnia szkoła Tarbut, partie polityczne, stowarzyszenie dobroczynne, było kilka synagog, cmentarz.

${ }^{21}$ Muzeum Narodowe w Krakowie (dalej: MNK), nr inw. MNK IV-Z-1276.

${ }^{22} \mathrm{MNK}, \mathrm{nr}$ inw. MNK IV-Z-1307.

${ }^{23} \mathrm{MNK}, \mathrm{nr}$ inw. MNK IV-M-3196. 
W tym samym roku zakupiono do zbiorów również dwie, dość zniszczone, niewątpliwie wycofane już z użytku, korony na Torę, pochodzące z synagog w Krzemieńcu i Dubnie, oraz kilka „rączek” - jadów, pochodzących również z Dubna ${ }^{24}$. Wśród obiektów z wyposażenia synagogi znalazły się, jak opisał Rabinowicz: „zwierciadła mosiężne” (odblaśnice) ze starej synagogi w Zawichoście ${ }^{25}$, zakupione przez muzeum za sumę 195 zł $^{26}$. Poza wymienionymi zakupiono też „reflektor” z synagogi w Ostrowcu [Świętokrzyskim] ${ }^{27}$. Dwie piękne posrebrzane nasadki na drzewce Tory, zwane ,rimonim”, pochodzące z nieistniejącej już XVIII-wiecznej synagogi w Chrzanowie, również trafiły do zbiorów krakowskich za pośrednictwem S. Rabinowicza ${ }^{28}$.

Poza obiektami synagogalnymi w zbiorach Muzeum Narodowego w Krakowie znalazło się też sporo przedmiotów używanych w domach żydowskich. Listę otwierają dwa zakupy z 1937 r.: „minojra wisząca” [menora] oraz pasek zakładany przez mężczyzn do białego kitla na święto Jom Kipur ${ }^{29}$. Wśród zakupów pojawiają się używane w domach świeczniki, w tym jeden pochodzący z Chęcin ${ }^{30}$, lampki chanukowe ${ }^{31}$ i napierśnik do stroju kobiecego ${ }^{32}$ oraz księga religijna Menorat Ha-maor, wydana w Sławucie w 1830 r. $^{33}$ Druga księga religijna została przez S. Rabinowicza podarowana $^{34}$. Tegoż roku zakupiono też kilka pięknie haftowanych,

\footnotetext{
${ }^{24}$ AMNK, Rachunki, sygn. LII/357.

${ }^{25}$ Trudno dokładnie zrozumieć informację S. Rabinowicza na temat pochodzenia obiektów ze „starej synagogi w Zawichoście”. Jest ona interesująca w kontekście innego zabytku, również pochodzącego z synagogi w Zawichoście, parochetu i kaporetu, który nabyty w 1938 r., początkowo znajdował się w synagodze w Sandomierzu, A. Lebet-Minakowska, Katalog..., s. 45. Należy wnioskować, że zmieniano wystrój synagogi lub przebudowywano ją.

${ }^{26}$ AMNK, Rachunki, sygn. LII/311.

${ }^{27}$ AMNK, Rachunki, sygn. LII/331.

${ }^{28}$ AMNK, Rachunki, sygn. LII/359.

${ }^{29}$ AMNK, Rachunki, sygn. XLIX/89; A. Lebet-Minakowska, Katalog..., s. 241.

${ }^{30}$ AMNK, Rachunki, sygn. XLIX/93.

${ }^{31}$ Lampa chanukowa - świecznik ośmioświecowy lub lampa oliwna zapalana podczas święta Chanuki na pamiątkę rekonsekracji Świątyni Jerozolimskiej podczas powstania Machabeuszy.

${ }^{32}$ Wymieniony na rachunku ,napierśnik” okazał się kołnierzem do kitla na Jom Kipur, A. Lebet-Minakowska, Katalog..., s. 225.

${ }^{33}$ AMNK, Rachunki, sygn. XLIX/95.

${ }^{34}$ MNK, nr inw. MNK VIII-XIX.1868 (Kitve kodesh, Wien: Anton Schmidt, 1837).
} 
aplikowanych koronką formowaną techniką ,szpanier arbajt”35 jarmułek, zakładanych przez mężczyzn z okazji znaczniejszych świąt religijnych (Rosz ha-Szana, Jom Kipur, Pesach) ${ }^{36}$.

W kolejnych latach do zbiorów zakupiono za pośrednictwem Rabinowicza sporo różnego rodzaju świeczników i lamp chanukowych ${ }^{37}, \mathrm{w}$ tym jedną drewnianą, unikatową w zbiorach polskich, pochodzącą z Przewor$\mathrm{ska}^{38}$. Niezwykle ciekawym obiektem jest też miseczka srebrna $\mathrm{w}$ formie trójliścia ${ }^{39}$. Nieco zagadkowe jest jej przeznaczenie, służyła zapewne do zbierania cedaki ${ }^{40}$ dla bractwa pogrzebowego Chewra Kadisza ${ }^{41}$ lub „ofiary pół szekla”, składanej początkowo na utrzymanie Świątyni Jerozolimskiej, a po jej upadku na potrzeby lokalnej synagogi. Chociaż czas jej składania przypadał na święta Paschy, jednak w dobrym tonie było ,wyprzedzić” ten termin i złożyć ofiarę podczas święta Purim ${ }^{42}$. Skarbonek, puszek do zbierania cedaki zakupiono od S. Rabinowicza więcej, w tym jedną z bożnicy w Baranowiczach, należącą pierwotnie do Bractwa Wiecznego Światła ${ }^{43}$. Zagadkowy przedmiot, określony na rachunku jako „sobotnik, pochodzący z Prużan", okazał się świecznikiem zapalanym w domu podczas świętowania szabatu ${ }^{44}$. Do zbiorów trafiły też dwa nożyki do obrzezania wraz z futerałami, w tym jeden z rękojeścią z chalcedonu, pochodzący z Chmielnika ${ }^{45}$, a drugi ze złoconą rękojeścią cyzelowaną, zdobioną filigranem i niellem, z Jarosławia ${ }^{46}$. Za pośrednictwem S. Rabinowicza w okresie międzywojen-

${ }^{35}$ Szpanier arbajt - rodzaj koronki klockowej wykonywanej z folii metalowej i nici lnianych na warsztacie do produkcji koronek klockowych.

${ }^{36}$ A. Lebet-Minakowska, Katalog..., s. 187, 196, 198.

${ }^{37}$ AMNK, Rachunki, sygn. XLIX 95; XLIX/105; XLIX/109; sygn. LII/305; LII/29.

${ }^{38}$ AMNK, Rachunki, sygn. LII/341.

${ }^{39}$ AMNK, Rachunki, sygn. XLIX/97.

${ }^{40}$ Cedaka - jałmużna.

${ }^{41}$ Bractwo Chewra Kadisz - bractwo pogrzebowe zajmujące się ceremoniałem pogrzebowym, przygotowaniem zwłok i pochówkiem.

${ }^{42}$ Ofiarowywano wówczas trzy razy po pół szekla, do zbierania takiej cedaki bardzo przydatna była skarbonka złożona z trzech odrębnych talerzyków lub pojemników.

${ }^{43}$ Chewra Ner Tamid - bractwo dbające o dostarczanie oliwy do lampy wiecznego światła (Ner Tamid) palącego się w synagodze, AMNK Rachunki, sygn. LII/345; MNK, nr inw. MNK IV-Z-962.

${ }^{44}$ AMNK, Rachunki, sygn. LII/343.

${ }^{45}$ AMNK, Rachunki, sygn. XLIX/97.

${ }^{46}$ AMNK, Rachunki, sygn. L II/335 (zakupiony 21 czerwca 1938 r. za 90 zł, obecnie: MNK, nr inw. MNK IV-Z-1313). 
nym do zbiorów muzealnych zakupiono blisko 150 różnych judaików, znajdujących się obecnie w zbiorach Muzeum Narodowego w Krakowie.

Analizując zabytki zakupione i darowane przez Rabinowicza, można stwierdzić, że pochodziły z różnych miejscowości i trudno tu wyróżnić jakiś konkretny region. Dokumentują one także szerokie spektrum życia żydowskiego. Znajdują się wśród nich przedmioty pochodzące z synagog: parochety i kaporety, sukienki na Torę, kijor ${ }^{47}$, korona nad bimę, świecznik synagogalny, reflektory czy nasadki na drzewce Tory, jady; przedmioty używane w domach: świeczniki i lampy szabatowe, puszki na wonności, kielichy kiduszowe ${ }^{48}$; elementy ubiorów kobiecych i męskich: czepce, załóżki i paski, naczynia do przyrządzania posiłków, nożyki do obrzezania, srebrne pojemniki na tefilin ${ }^{49}$, klocki i matryce do sporządzania odbitek, ,amulet dla położnicy" ${ }^{50}$, pieczęć i książki religijne. Powyższy pobieżny ich przegląd pozwala wnioskować, że zakupiona wówczas kolekcja rzemiosła jest jednym z najciekawszych zbiorów judaistycznych w Polsce, a pośrednik w ich pozyskaniu postacią ze wszech miar ciekawą i wartą upamiętnienia. Szczególnie że znaczna część zakupionych od niego obiektów została do tej pory opracowana i jest eksponowana w ramach stałej ekspozycji w Głównym Gmachu Muzeum Narodowego w Krakowie. Poza listą zakupionych od niego zabytków, rachunkami i pokwitowaniami odbioru pieniędzy z lat 19361938, dotychczas nie wiedzieliśmy o nim niczego. Znaliśmy tylko nazwisko i ówczesny adres zamieszkania przy ulicy Wita Stwosza w krakowskim Podgórzu, numer domu $11^{51}$. Poszukiwania utrudniał fakt, że budynek nr 11 wraz z całą zachodnią stroną ulicy został w 1941 r. włączony w obszar

\footnotetext{
${ }^{47}$ Kijor - pojemnik na wodę ustawiany przy wejściu do synagogi, służył do rytualnych ablucji.

${ }^{48}$ Kielich kiduszowy (hebr. kidusz - poświęcenie) - kielich służący do błogosławieństwa wina podczas świąt żydowskich.

49 Tefilin - akcesoria modlitewne używane przez mężczyzn, zazwyczaj są to dwa pudełeczka ze skóry koszernego zwierzęcia, w których umieszczone są spisane ręcznie fragmenty tekstów Tory.

${ }^{50}$ Pod tą nazwą obiekt został kupiony i wpisany do księgi inwentarzowej, taka nazwa widnieje też na rachunku. Nie jest to jednak amulet odciśnięty na papierze, ale płyta miedziorytnicza do sporządzania odbitek amuletów z 1832 r., autor: Mordechaj Sofer (Markus Donath), Słowacja, Nitra, MNK, sygn. IV-M-2116.

${ }^{51}$ Dom opatrzony tym numerem stoi do dzisiaj na krakowskim Podgórzu. Po II wojnie światowej nazwa ulicy została zmieniona i obecnie nazywa się Piwna. W oficynie budynku znajdowało się pierwotnie sporo niewielkich sklepików.
} 
getta żydowskiego, którego mieszkańcy, systematycznie od 1942 r., wywożeni byli do obozu zagłady w Bełżcu, a podczas likwidacji getta w $1943 \mathrm{r}$. wszyscy zostali wysiedleni do obozu w Płaszowie. Po II wojnie światowej w kamienicy przy ulicy Piwnej 11 nie mieszkał już nikt, kto pamiętałby jej dawnych lokatorów. Problemem też stało się potwierdzenie zameldowania S. Rabinowicza pod wspomnianym adresem w księgach meldunkowych z 1936 r., te bowiem zaginęły, prawdopodobnie zostały zniszczone tuż przed lub podczas niemieckiej okupacji ${ }^{52}$.

Nigdy wcześniej nie przeprowadzano kwerend archiwalnych, aby dowiedzieć się o nim czegoś więcej. Wynikało to z uprzedzeń i przekonania, że jest niewartym uwagi, niewykształconym „,chałatowym Żydem”, handlarzem starzyzną, jakich wielu. Prowadzone około dziesięciu lat temu poszukiwania zakończyły się niepowodzeniem, dopiero kwerendy w Archiwum Narodowym w Krakowie, Żydowskim Instytucie Historycznym, United States Holocaust Memorial Museum w Waszyngtonie i Jad wa-Szem w Jerozolimie, przyniosły rezultaty.

W Archiwum Narodowym w Krakowie na kartach Spisu ludności miasta Krakowa z 1921 r. odnotowano Szymona Rabinowicza, bez zawodu, wyznania mojżeszowego, narodowości żydowskiej, deklarującego język ojczysty ,żargon” (tj. jidysz), zamieszkałego pod adresem: ulica Kupa 1 w dzielnicy VIII (Kazimierz). Według spisu mieszkał w Krakowie na stałe od 1917 r. Również od 1917 r. mieszkała w Krakowie wymieniona wraz z nim żona rytualna (tak dosłownie odnotowano na karcie) Helena Kremmer. Mieli dwoje dzieci (wymienione wraz z matką): bliźnięta

52 Poszukiwania dodatkowo utrudniła sugestia kustoszki, która powołując się na wspomnienia osoby pracującej w muzeum przed II wojną światową, kategorycznie twierdziła, że S. Rabinowicz nie mieszkał nigdy w Krakowie, przyjeżdżał jedynie co jakiś czas do miasta, przywożąc i sprzedając judaika. Pochodził z Wołynia, gdzie mieszkał, a przy ul. Wita Stwosza zatrzymywał się u znajomych lub rodziny, przebywając czasowo w mieście, i ten adres podawał do rozliczeń z Muzeum, ponieważ był zobowiązany podać miejsce zamieszkania w Krakowie. Stąd moje pierwsze poszukiwania koncentrowały się wokół Yzkor - Ksiąg Pamięci dotyczących miejscowości przedwojennego województwa wołyńskiego i kresów wschodnich. Poszukiwania te okazały się ślepą uliczką, nazwisko Rabinowicz pojawiało się bardzo często, a wobec braku innych danych personalnych ustalenie, która z wymienionych osób może być S. Rabinowiczem, handlarzem sprzedającym judaika do zbiorów Muzeum Narodowego w Krakowie - niemożliwe. 
Chanę i Natana urodzone 28 grudnia $1918 \mathrm{r} .{ }^{53}$ Nie potwierdza to jeszcze teorii, że jest on tożsamy z S. Rabinowczem, który podpisywał muzealne rachunki z lat 1936-1938. Widnieje na nich bowiem inny adres jego zamieszkania. Dopiero odnalezienie informacji, że w 1936 r. (gdy sprzedawał do Muzeum Narodowego w Krakowie pierwsze obiekty) zameldowany był w Krakowie przy ulicy Wita Stwosza w domu nr 11, wskazuje, że była to ta sama osoba ${ }^{54}$. Adres zameldowania co prawda pokrywał się z lokalizacją zamieszkania jego i rodziny umieszczoną na rachunkach zachowanych w Archiwum Muzeum Narodowego w Krakowie i podawaną przez S. Rabinowicza jako miejsce zamieszkania w Krakowie, ale w Spisach ludności miasta Krakowa brak informacji o wykonywanym zawodzie. Nadal więc można by mieć wątpliwości, czy wymieniona osoba to poszukiwany „handlarz starzyzną”, który sprzedał do zbiorów Muzeum Narodowego w Krakowie tyle cennych przedmiotów rzemiosła artystycznego. Z informacji podanych na rachunkach znajdujących się w Archiwum Muzeum Narodowego w Krakowie (w tym miejsca zameldowania) wynika, że rodzina Rabinowiczów pod wymienionym adresem mieszkała aż do 1939 lub 1940 r. Wniosek taki nasuwa się po zapoznaniu się z kolejnymi dokumentami pochodzącymi z okresu niemieckiej okupacji: wnioskami o dowody osobiste, nakazami przesiedlenia i odwołaniami od decyzji oraz zaświadczeniami z Arbeitsamtu, znajdującymi się w Archiwum Narodowym w Krakowie $^{55}$. Z zawartych w dokumentach informacji dowiadujemy się, że Samuel Simcha Rabinowicz (ur. 16 grudnia 1893 r. w miejscowości Frysztak koło Strzyżowa) w marcu 1940 r. mieszkał w Krakowie, w dzielnicy XXII,

${ }^{53}$ ANK, Spis ludności miasta Krakowa z r. 1921, sygn. 29/91/14, s. 462, poz. 6704 (Szymon Rabinowicz) i 6705 (Helena Kreimer, jego żona rytualna, tj. bez ślubu cywilnego, jednak mieszkająca pod wspólnym adresem). W spisie jako początek jego stałego pobytu w Krakowie podany jest 1917 r., natomiast składając w 1941 r. wniosek o wydanie Kennkarty, Rabinowicz podał, że mieszka w Krakowie od 1914 r., w latach 1914-1917 służył w wojsku austriackim, podczas I wojny światowej walczył na froncie austriacko-rosyjskim, w 1917 r. został ranny i zwolniony z wojska jako inwalida wojenny, wrócił do Krakowa.

${ }^{54}$ ANK, Urząd Zdrowia w Krakowie, Księga urodzin Chrześcijan i Izraelitów z 1936 r., t. 1, sygn. 29/83/8/412, poz. 3511. Chciałabym w tym miejscu bardzo podziękować za pomoc Tomaszowi Wrońskiemu, kustoszowi ANK za podpowiedź i okazaną mi pomoc. Bez jego cennych sugestii problem nie zostałby do końca wyjaśniony.

${ }_{55}$ ANK, Akta Miasta Krakowa, Kwestionariusze na wydawanie dowodów osobistych (Kennkarten) dla Żydów - załatwione pozytywnie: litera Ra, sygn. 29/33/5.6.4/SMKr 537, s. 419. 
przy ulicy Zakopiańskiej (Zakopanerstrasse) w domu nr 21, na II piętrze (II kondygnacji), w mieszkaniu (lokalu) $\mathrm{nr} 16$. Według podanych przez niego informacji w Krakowie mieszkał od 1914 r. Jego wyuczony zawód to krawiec, ale ,zawodowo” zajmował się zbieraniem starych, zużytych tkanin (dziś nazwalibyśmy go „handlarzem starzyzną”), a w okresie okupacji także przerabianiem surowców wtórnych i odpadów. W dokumentach pojawia się niemieckie słowo „Lumpensammler” - szmaciarz, łachmaniarz, gałganiarz. Zatrudniony był w firmie „Simplak” mieszczącej się w Krakowie przy ulicy Rzeszowskiej 7 (Rzeszowskagasse). Wraz z nim w wyżej wymienionym „lokalu” mieszkali: żona Fejga Rabinowicz (ur. 1895 r., Nowy Korczyn), córki: Chana (ur. 28 grudnia 1918 r., Kraków), Pepi (ur. 19 kwietnia 1922 r., Kraków) i Chaja (ur. 2 października 1936 r.), synowie: Natan (ur. 28 grudnia 1918 r., Kraków), Majer (ur. 10 października 1924 r., Kraków) i Naftali (ur. 3 czerwca 1926 r., Kraków). Na formularzu znajduje się także informacja, że Szymon był żołnierzem austriackim, służył w 32 Regimencie, walczył na rosyjskim froncie w latach 1914-1917, gdzie w 1917 r. został ranny w prawe ramię i dostał się do niewoli rosyjskiej. Otrzymał medal za odwagę i krzyż walecznych, był więc oficjalnie zarejestrowanym austriackim inwalidą wojennym, w księdze inwalidów wojennych nr $2169^{56}$. Powołując się na swoje zasługi wojenne, odniesione rany i odznaczenia, S. Rabinowicz odwołał się od decyzji nakazu przesiedlenia, załączył też informacje o chorobie czternastoletniego syna, który od jedenastu lat chorował na gruźlicę stawów, poparte lekarskim zaświadczeniem ${ }^{57}$. Decyzja została odroczona, niestety nie na długo.

W złożonym przez niego w $1941 \mathrm{r}$. kwestionariuszu na wydanie dowodu osobistego S. Rabinowicz podał jako miejsce zamieszkania adres przy ulicy Kalwaryjskiej 21, numer mieszkania 16 - to taki sam numer domu i mieszkania jak w 1940 r. ${ }^{58} \mathrm{~W}$ marcu 1941 r. S. Rabinowicz otrzymał ko-

${ }^{56}$ ANK, Akta Miasta Krakowa, Kwestionariusze..., sygn. 29/33/5.6.4/SMKr 537, s. 419.

${ }^{57}$ Ibidem, s. 437. S. Rabinowicz załączył stosowne zaświadczenie lekarskie dr R. Fuchs-Katsowej, ANK, Akta Miasta Krakowa, Kwestionariusze..., sygn. 29/33/5.6.4/SMKr 537, s. 433.

${ }^{58}$ Miasto Podgórze zostało przyłączone do Krakowa w 1915 r. Obecna ul. Kalwaryjska wielokrotnie zmieniała nazwę: Trakt Izdebnicki (1789-1910); Kalwaryjska (1910-1940); Zakopanerstrasse (1940-1945); Kalwaryjska (1945-1950); Wincentego Pstrowskiego (1950-1990) i znowu Kalwaryjska (od 1991 r.), Elżbieta Supranowicz, Nazwy ulic Krakowa, Kraków 1995, s. 68; Michał S majdor, Wykaz zmian nazwalei, mostów, osiedli, 
lejny nakaz opuszczenia mieszkania i został wraz z rodziną przesiedlony do getta $^{59}$, ponieważ ta część ulicy Zakopiańskiej (Kalwaryjskiej) znajdowała się już poza jego granicami. 10 marca $1941 \mathrm{r}$. Rabinowicz napisał powtórne odwołanie od nakazu przesiedlenia, w którym zwraca się z prośbą, aby nie rozdzielano go z dziećmi i cała jego rodzina mogła pozostać razem z nim w „kwartale żydowskim”. W piśmie S. Rabinowicz podał adres zamieszkania w Krakowie-Podgórzu przy ulicy Zakopiańskiej 21/16, gdzie mieszkał wraz z rodziną: żoną i dwójką dzieci: synem Majerem Rabinowiczem i córką Pepi Rabinowicz (nazwisko matki: Kremmer), starsza córka Chana (nr Kennkarty 08860) nie mieszkała już z nim, ponieważ została przymusowo przesiedlona do Bychawy w dystrykcie lubelskim. On sam zaś był inwalidą wojennym, zbieraczem ,odpadów” i tkanin (starzyzny), w pracy pomagał mu syn Majer ${ }^{60}$. Pomimo odwołania S. Rabinowicz wraz z rodziną otrzymał nakaz opuszczenia domu i udania się na miejsce zbiórki przy ulicy Mogilskiej 1, mógł zabrać ze sobą nie więcej niż 25 kilogramów bagażu oraz prowiant na 3 dni. Pozostały dobytek miał trafić do Urzędu Powierniczego, mieszkanie należało zamknąć, a klucze zostawić u dozorcy. Złożone przez S. Rabinowicza odwołanie od decyzji zostało rozpatrzone negatywnie ${ }^{61}$.

parków, placów, rond i ulic w Krakowie, http://www.kmk.krakow.pl/artykul_nazwy_ulic. html (odczyt: 02.11.2018). Wymieniona kamienica stoi w tym miejscu do dnia dzisiejszego, obecny adres to ul. Kalwaryjska 21.

${ }^{59}$ Getto krakowskie zostało powołane zarządzeniem gubernatora dystryktu krakowskiego dr. Otto Wächtera z 3 marca 1941 r. Przesiedlenie planowano zakończyć 21 marca, od tego dnia getto miało zostać zamknięte, Martyna Grądzka-Rejak, Nikt nie wierzy w petna zagładę. Akcja , Reinhard” w okupowanym Krakowie, „Biuletyn IPN” 2017, nr 6 (139), s. 26.

${ }^{60}$ ANK, Akta Miasta Krakowa, Kwestionariusze..., sygn. 29/33/5.6.4/SMKr 537, s. 429.

${ }^{61}$ Ibidem, s. 409-415, 417, 419, 421-431, 435, 437-439, 443 (odwołanie od decyzji o przesiedleniu); ANK, Akta Miasta Krakowa, Listy imienne Żydów przeznaczonych do wysiedlenia z Krakowa w dniach 5 i 6 XII 1940, 24 i 31 I 1941 oraz 4 i 17 II 1941 r., mających zgłosić się w obozie Lubicz w Krakowie (ul. Mogilska 1), sygn. 29/33/5.6.6/SMKr 772 (Szymon Rabinowicz poz. 1459, Chaja Rabinowicz poz. 1451, Feiga Rabinowicz poz. 1452, Natan Rabinowicz poz. 1453, Chana Rabinowicz poz. 1454, Pepi Rabinowicz poz. 1455, Majer Rabinowicz poz. 1456, Naftali Rabinowicz poz. 1457); ANK, Dane osobowe Żydów ze zdjęciami w układzie wg numerów Kennkart (numery: 8689-8900), sygn. 29/1576/28: Rabinowicz Samuel Symcha, s. 89, poz. 8866 (Kennkarta nr 08866); Rabinowicz Chana, s. 87, poz. 8860 (Kennkarta nr 08860); Fajgla z d. Kremmer s. 88, poz. 8863 (Kennkarta nr 08863); Rabinowicz Naftali, s. 88, poz. 8864 (Kennkarta nr 08864). 
Wspomniane wyżej dokumenty z 1941 r. są ostatnimi zachowanymi w Archiwum Narodowym w Krakowie, o dalszych losy rodziny dowiadujemy się z zeznań i informacji świadków zachowanych w archiwum Jad wa-Szem.

Córka Chana (w dokumentach pojawia się też jako Hanna), która w lutym 1941 r. została deportowana do pracy w miejscowości Bychawa koło Lublina, jako jedyna z rodziny Rabinowiczów przeżyła Szoa i II wojnę światową, choć wydawałoby się, że przesiedlenie w kierunku Lublina oznaczało deportację do obozu w Majdanku. Po II wojnie światowej mieszkała w Stanach Zjednoczonych Ameryki, jej świadectwa udokumentowane są w archiwum Jad wa-Szem ${ }^{62}$ i są głównym źródłem informacji na temat losów jej ojca Szymona, matki i rodzeństwa, jednak bliższe dzieje rodziny pozostają nadal nieznane ${ }^{63}$.

${ }^{62}$ Tak zwany „List Świadka do zbierania i utrwalenia pamięci żydów zamordowanych w Zagładzie - Shoah”, ankiety wypełniane przez osoby żyjące, świadków zagłady Żydów podczas II wojny światowej, rejestrowane i przechowywane w Archiwum Jad wa-Szem - Instytucie Pamięci Męczenników i Bohaterów Holocaustu mieszczącym się w Jerozolimie na Har Hazikaron (Wzgórzu Pamięci). Materiały te są obecnie udostępniane online jako baza danych: Yad Vashem the World Holocaust Remembrance Center, The Central Database of Shoah Victims' Names, https://yvng.yadvashem.org/nameDetails. html?language $=$ en\&itemId=..\&ind $=1$. Przy czym w miejsce kropek należy wpisać wartość itemId, stąd dalej cytowane będą jako np.: Yad Vashem, Vicims'Names, itemId: 10408088, co oznacza że dana karta jest dostępna pod adresem https://yvng.yadvashem.org/nameDetails.html?language $=$ en\&itemId $=10408088$ \&ind $=1$.

${ }^{63}$ Członkowie rodziny Szymona, poza Chaną, nadal znajdują się na liście zaginionych i poszukiwanych w ewidencji Jad wa-Szem. Na podstawie zachowanych dokumentów udało się ustalić jedynie losy Natana, syna Rabinowicza, który trafił do Auschwitz w 1941 r., został zarejestrowany 5 kwietnia tegoż roku, miał wówczas 23 lata (Rabinowicz Natan, numer więźniarski: 12013, urodzony: 28 grudnia 1918, miejsce urodzenia: Kraków. Auschwitz, przybycie do obozu 5 kwietnia 1941), Miejsce Pamięci i Muzeum Auschwitz-Birkenau, Informacja o więźniach, http://auschwitz.org/muzeum/informacjao-wiezniach/ (odczyt: 02.11.2018). W ewidencji Jad wa-Szem imię i nazwisko Natan Rabinowicz występuje dwa razy, ponieważ daty urodzenia są takie same, można domniemywać, że chodzi o tę samą osobę. W pierwszym dokumencie przy imieniu i nazwisku Natana Rabinowicza pojawia się informacja: syn Feli Kremer i Szymona Rabinowicza, lat 21, pisarz, dziennikarz, zginął w Getto w Krakowie (Yad Vashem, Vicims' Names, itemId: 10408088), w drugim zamieszczona jest informacja: Natan Rabinowicz, wyuczony zawód - krawiec, zginął w Dachau, dnia 23 lutego 1942 (Yad Vashem, Vicims' Names, itemId: 741217). W Centralnej Bazie Ofiar Shoah Jad wa-Szem zarejestrowany jest także Natan Kremer: ur. 28 grudnia 1920 Kraków, zm. Dachau, syn Cipory Kremer i Szymona Rabinowicza (Yad Vashem, Vicims'Names, itemId: 418075), wg informacji siostry Khany 
Na podstawie przeprowadzonych badań udało mi się ustalić, że Szymon Samuel [Samuel Simcha] Rabinowicz ${ }^{64}$ nie pochodził z Wołynia, jak sugerowano, ale urodził się 16 grudnia 1895 r. w miejscowości Frysztak koło Strzyżowa. Do Podgórza przybył w 1914 r. (lub 1917 r.) i tu osiadł na stałe $^{65}$. W latach 1914-1917 służył w armii austriackiej na froncie rosyjskim, gdzie w 1917 r. został ranny, początkowo trafił do szpitala, a następnie został zwolniony $\mathrm{z}$ armii i wpisany $\mathrm{w}$ poczet inwalidów wojennych. W 1918 r. (lub 1925 r.) ożenił się z Fejgą [Fela, Pola], z domu Kremmer, urodzoną w Nowym Korczynie w 1895 r. ${ }^{66} \mathrm{Z}$ tego związku urodziło się sześcioro dzieci, których dalszych, bardziej szczegółowych losów, nie

Cherklevitz. Data urodzenia i imiona rodziców są tożsame z datą urodzenia i imionami rodziców Natana Rabinowicza, nazwisko Kremmer jest nazwiskiem panieńskim matki, która, jak pokazano wyżej w spisie ludności z 1921, jest zapisana pod nazwiskiem panieńskim (jako żona rytualna, tj. bez ślubu cywilnego), można więc przyjąć, że Natan Rabinowicz i Natan Kremer to ta sama osoba. Podstawą do informacji jest lista obywateli polskich, którzy zginęli w Dachau, 1939-1945, Teodor Musioł, Dachau 1933-1945, Opole 1971, s. 403 , poz. 849 .

${ }^{64}$ Samuel (Symcha) Szymon Rabinowicz (ur. 16 grudnia 1895, Frysztak koło Krosna 1942 Treblinka), ANK, Akta poniemieckie, sygn. 29/1576/28, s. 89 (Kennkarta nr 8866); Centralna Biblioteka Judaistyczna ŻIH, Ankiety personalne osób skierowanych do wysiedlenia z Krakowa, sygn. 218/34/176/61; Yad Vashem, Vicims'Names, itemId: 513659 i 10408038, wg relacji córki Khany Cherklevitz zginął w getcie w Krakowie lub w transporcie z Płaszowa został wysłany do obozu zagłady w Treblince.

${ }^{65}$ Ausweis na nazwisko Szymon Rabinowicz, nr 34881, ur. 16 grudnia 1895, zam. Kraków, ul. Kalwaryjska 21, wydano 18 grudnia 1940, ANK, Akta Miasta Krakowa, Kwestionariusze..., sygn. 29/33/5.6.4/SMKr 537, s. 417, 437; ANK, Wykazy dowodów osobistych..., sygn. 29/33/0/5.6.4/SMKr 450, s. 443; ANK, Akta poniemieckie, Dane osobowe Żydów..., sygn. 29/1576/28 s. 88-89, poz. 8866 (Rabinowicz Samuel Symcha).

${ }^{66}$ Fajga (Fela) Rabinowicz z domu Kremmer (ur. 1895 Nowy Korczyn koło Buska, zm. 1941, getto w Krakowie-Podgórzu), żona Samuela, Symcha (Szymon) Rabinowicza, miejsce zamieszkania: Kraków, ul. Zakopiańska 21, ANK, Akta poniemieckie..., sygn. 29/1576/28, s. 88-89 (Kennkarta nr 08863 wydana 6 marca 1941); ANK, Akta Miasta Krakowa, Wykazy dowodów osobistych..., sygn. 29/33/5.6.4/SMKr 450, s. 443; Yad Vashem, Vicims' Names, itemId: 513568. Wg informacji w dokumencie: „List Świadka do zbierania i utrwalenia pamięci Żydów zamordowanych w Zagładzie - Shoah" - świadectwa córki Khany Cherklevitz, zginęła w getcie krakowskim w 1941 r. 
udało mi się poznać, były to: bliźnięta $\mathrm{Chana}^{67}$ i $\mathrm{Natan}^{68}, \mathrm{Pepi}^{69}, \mathrm{Majer}^{70}$, Naftali $^{71}$, Chaja ${ }^{72}$.

S. Rabinowicz był osobą niezwykle mobilną. Dzięki jego „etnograficznym podróżom" w różne rejony Polski, pośredniczeniu w kupnie judaików, obecne zbiory rzemiosła żydowskiego są tak liczne i różnorodne. Do dnia dzisiejszego stanowią one największą i najcenniejszą kolekcję pozyskanych w okresie międzywojennym judaików i są doskonałymi przykładami XVII-, XVIII- i XIX-wiecznego rzemiosła żydowskiego, odzwierciedlającego szerokie spektrum życia codziennego i religijnego. Wszystkie zakupione od S. Rabinowicza przedmioty noszą ślady zużycia, zgodnie z informacją przekazaną przez F. Koperę do Ministerstwa Wyznań Religijnych i Oświecenia

${ }^{67}$ Chana Rabinowicz (ur. 28 grudnia 1918, Kraków, Polska, zm. ok. 2002), krawcowa, ANK, Akta poniemieckie..., sygn. 29/1576/28, s. 89, poz. 8860 (Rabinowicz Chana); Yad Vashem, Vicims' Names, itemId: 10407719. Lista Żydów deportowanych zrobiona przez Niemców, Transport do Lublina, dnia 25 lutego 1941. Transport No. 16. Przeżyła, wypełniła: „Listy Świadka do zbierania i utrwalenia pamięci Żydów zamordowanych w Zagładzie - Shoah" w Jad wa-Szem jako Khana Cherklevitz w 1955 r.

${ }^{68}$ Natan Rabinowicz (ur. 28 grudnia 1918, Kraków, Polska - zm./zamordowany 23 lutego 1942 Dachau, Obóz Zagłady, Niemcy), syn, zawód: krawiec, ANK, Akta Miasta Krakowa, Kwestionariusze..., sygn. 29/33/5.6.4/SMKr 537, s. 443; ANK, Akta poniemieckie..., sygn. 29/1576/28, s. 88-89; Yad Vashem, Vicims' Names, itemId: 10408088 i 741217, wg relacji siostry Khany Cherklevitz był pisarzem i dziennikarzem. Dnia 5 kwietnia 1941 przywieziony do Auschwitz z transportem Polaków z więzień w Tarnowie, Montelupich w Krakowie i SIP (Stowarzyszenie Interwencji Prawnej), liczącym 933 mężczyzn, zarejestrowany pod numerem 12013 (numer więźniarski, dane osobowe: ur. 28 grudnia 1918, miejsce urodzenia Kraków), Księga Pamięci. Transporty Polaków do KL Auschwitz z Krakowa i innych miejscowości Polski potudniowej 1940-1944, t. 1, Kraków 2002, red. Franciszek Piper, Irena Strzelecka, s. 538, poz. 12013.

${ }^{69}$ Pepi Rabinowicz (ur. 19 kwietnia 1922, Kraków, Polska - zm.?), ANK, Akta poniemieckie..., sygn. 29/157628, s. 89; ANK, Akta Miasta Krakowa, Kwestionariusze..., sygn. 29/33/5.6.4/SMKr 537, s. 443; Yad Vashem, Vicims' Names, itemId: 10408124, wg relacji siostry Khany Cherklevitz zmarła w Bergen Belsen.

${ }^{70}$ Majer Rabinowicz (ur. 10 października 1924, Kraków, Polska - zm.?), ANK, Akta poniemieckie..., sygn. 29/157628, s. 89; ANK, Akta Miasta Krakowa, Kwestionariusze..., sygn. 29/33/5.6.4/SMKr 537, s. 443; Yad Vashem, Vicims' Names, itemId: 870026, 514555 i 10408146, wg informacji siostry Khany Cherklevitz zginął w getcie w Krakowie.

${ }^{71}$ Naftali Rabinowicz (ur. 3 kwietnia 1926 Kraków, Polska - zm.?), ANK, Akta poniemieckie..., sygn. 29/1576/28, s. 89 (Kennkarta nr 8864); Yad Vashem, Vicims' Names, itemId: 8750025,10407917 i 8749991.

${ }^{72}$ Chaja Rabinowicz (ur. 2 października 1936 Kraków, Polska - zm.?), ANK, Akta poniemieckie..., sygn. 29/1576/28, s. 89; Yad Vashem, Vicims' Names, itemId: 10408056. 
Publicznego kupowano wyłącznie obiekty zniszczone, wycofane z użytku i sprawowania kultu religijnego, a więc takie, które i tak zostałyby przerobione lub zniszczone.

S. Rabinowiczowi nie sposób odmówić znajomości zagadnienia, dobrej orientacji w judaikach, wszystkie zakupione od niego przedmioty są bardzo ciekawymi przykładami rzemiosła artystycznego, a niektóre z nich są wręcz unikalne, jak wspomniane wyżej sziwiti czy drewniana chanukija. Nie był z pewnością, jak pogardliwie się o nim wyrażano „Żydem chałatowym", na fotografiach widzimy mężczyznę w sile wieku, ubranego w garnitur i krawat. Jak wielu z jego pokolenia podzielił tragiczne dzieje swojego narodu, mam jednak nadzieję, że dzięki uzyskanym informacjom na jego temat i próbie zrekonstruowania losów nie pozostanie anonimowy i zapomniany, bowiem znacznie się przyczynił do zachowania pamięci o swoich aszkenazyjskich współbraciach. Z punktu widzenia historii kolekcjonerstwa i dziejów powstania zbiorów judaistycznych Muzeum Narodowego w Krakowie jest postacią niezwykle interesującą.

\section{ANEKS I}

\section{Notatka z posiedzenia w MWRiOP ${ }^{73}$}

Po przedstawieniu nieodzownej konieczności zabezpieczenia zabytków synagogalnych przed zniszczeniem i ewentualnym wywozem, przez pana naczelnika Zawistowskiego, zabrał głos pan dyrektor Kopera, mówił o potrzebie natychmiastowego zorganizowania działu sztuki żydowskiej przy Muzeum Narodowym w Krakowie. Założenie bowiem takiego oddziału ochroniłoby w przyszłości niszczenie i rozpraszanie zabytków bezpośrednio z kulturą polską związanych. Po wyczerpującej dyskusji p. dyr. Potocki oświadcza, że postara się uzyskać z kredytów departamentu Wyznań (p. 14 dział II) kwotę około 10000 zł na cele zabezpieczenia zabytków synagogalnych.

Wobec powyższego ustalono, że powyższa kwota w razie jej asygnowania zostałaby przez Departament Wyznań przekazana Zarządowi Miejskiemu miasta stołecznego Krakowa z wyraźnym zaznaczeniem, że ma być użyta wyłącznie na cele zabezpieczenia zabytków synagogalnych z tym, że departament Wyznań otrzyma szczegółowe sprawozdanie $\mathrm{z}$ użycia tej sumy.

Pan dyrektor Kopera w imieniu Prezydenta miasta stołecznego Krakowa oświadcza, że przekazana suma zostałaby przez Zarząd Miejski doręczona Muzeum Narodowemu

\footnotetext{
${ }^{73}$ AMNK, Zbiory i zakupy 1935, sygn. L/189c.
} 
w Krakowie do jego dyspozycji i wyłącznie zużyta na cele zabezpieczenia zabytków synagogalnych.

Pan dyrektor Kopera oświadcza, że przekazaną Muzeum Narodowemu w ten sposób sumą dysponowałby jedynie na cele zabezpieczenia zabytków synagogalnych przy czym ewentualne zakupy dokonywane będą w porozumieniu i za zgodą Wydziału Sztuki Ministerstwa WRiOP.

\section{ANEKS II \\ Sprawozdanie dyrektora Muzeum Narodowego w Krakowie Feliksa Kopery do MWRiOP ${ }^{74}$}

23 września [1930] 8r.

Do Ministerstwa Wyznań Religijnych i Oświecenia Publicznego Wydział Sztuki w Warszawie

Sprawozdanie z zakupu zabytków judaistycznych, nabytych w 1938 roku z subwencji ministerstwa W.R. I O.P. w kwocie 3.000 zł, przyznanej Muzeum Narodowemu w Krakowie pismem ministerstwa z dnia 21 stycznia 1938 r. No Szt-190/38.

W roku sprawozdawczym /t.j. Od 21 stycznia do 20 września 1938 r./ Dyrekcja Muzeum Narodowego uzupełniła zbiory z działu ,iudaiców” wielu wartościowymi przedmiotami kultu żydowskiego, jak srebra służące do praktyk religijnych w synagogach i domach prywatnych/ tarcze na Torę, rączki do wskazywania przy czytaniu Tory, balsaminki, nasadki i korony na rodały ${ }^{75}$, świeczniki, puszki, naczynia i t.d./, lampy chanukowe, tkaniny i t.p., starając się o pozyskanie dla kolekcji rzadkich już i trudnych do zdobycia zabytków.

W pierwszej grupie przedmiotów /srebra/ znaczną pozycję stanowią tarcze na Torę, które w większości pochodzą z XVIII wieku. Motywy właściwe zabytkom żydowskim /lwy, jednorożce, korony, tablice z przykazaniami/ łączą się na nich z różnoraką stylową ornamentacją. Wydatnie zwiększyła się też nasza kolekcja srebrnych rączek do wskazywania przy czytaniu Tory, które w licznych odmianach zdołaliśmy zebrać, starając się zwłaszcza o okazy z napisami. Różne typy wskazują także puszki na wonne korzenie /balsaminki/ o najrozmaitszych kształtach /wieżyczki z chorągiewkami, gruszki, miniaturowej szkatułki ażurowej/ powstały zaś /podobnie jak rączki/ w wieku XVII, XVIII i w pierwszej połowie XIX w. Do sreber służących do praktyk pobożnych należą wreszcie dwie korony z XVIIIXIX w., nasadki na rodały, z których jedna para pochodzi z XVII w., wazka z drugiej połowy XVIII w. i puszka srebrna do zbierania pieniędzy w synagodze z motywami XVII w.

W srebrze, brązie i drzewie wykonano nabyte lampy chanukowe i świecznik sobotni, które stanowią główne zabytki z XVIII stulecia. Piękny nasz zbiór reflektorów wzbogacił się okazami z XVII i XVIII wieku. Do rzadkich okazów należy lichtarz na palmy na święto Kuczek z XVI-XVIII w. i ołtarzyk żydowski z XVIII wieku. Nabyliśmy wreszcie parę naczyń obrzędowych, reprezentujących wiek XVII-XIX.

\footnotetext{
${ }^{74}$ AMNK, Korespondencja Feliksa Kopery, sygn. XLIX/115.

${ }^{75}$ Zwoje Tory.
} 
Dzięki szczęśliwym okazjom zakupiliśmy kilka zasłon do naszego zbioru tkanin żydowskich. Najwięcej wartościowa jest zasłona na szafę ołtarzową /purojches/ w stylu Ludwika XIV, bogata i typowa, z brokatu o pięknym ornamencie roślinnym, z lambrekinem /parochet/ o wypukłym, wspaniałym hafcie, przedstawiającym koronę, skrzydlate lwy i stylizowane tulipany. Dwie dalsze zasłony pochodzą z pierwszej i drugiej połowy XVIII w. Starsza z nich naszyta jest brokatem o ciekawej, zamkniętej kompozycji. Część wreszcie subwencji przeznaczyliśmy na konserwację zabytków tego działu; m.in. naprawiono zasłonę zrobioną z chińskiej makaty.

Kończąc sprawozdanie nadmieniamy, że przez zakup przedmiotów kultu żydowskiego ratuje się od rozproszenia i ostatecznego zniszczenia resztki zabytków, które w wielkiej części są dziełem rąk polskiego rzemieślnika /n.np reflektory/. Przedmioty przez nas nabyte były wycofane $\mathrm{z}$ użytku jako podniszczone albo nie nadające się do kultu. Pozostawione swemu losowi albo zmarniałyby, albo też dostały się w ręce niepowołane i jak wiele innych okazów znalazłyby się w znacznej części w zbiorach zagranicznych. Najlepszym zatem sposobem ocalenia tych zabytków jest wyszukiwanie ich na wszystkich ziemiach Polskich przez odpowiednich żydowskich starozakonnych /ortodoksów/ handlarzy starzyzny, zakupywanie do Muzeum i tu konserwowanie umiejętne. W ogóle zabytków polsko-żydowskich u nas jest teraz mało i tak trudno o nie, że jest to ostatnia pora, aby ocalić to, co jeszcze do naszych czasów dotrwało. Dlatego zwracam się z prośbą o dalszą subwencję w kwocie 3.000 zł na skupywanie i konserwację nie nadających się do kultu, zniszczonych zabytków polsko-żydowskich.

/Dyrektor Muzeum Narodowego/

w załączeniu zestawienie rachunków z 31 odpisami.

\section{BIBLIOGRAFIA}

\section{Źródla rękopiśmienne}

Archiwum Muzeum Narodowego w Krakowie

Korespondencja Feliksa Kopery, sygn. XLIX/115.

Rachunki, sygn. XLIX/89, XLIX/93, XLIX/95, XLIX/97, XLIX/105, XLIX/109, LII/29, LII/305, LII/311, LII/331, L II/335, LII/341, LII/343, LII/345, LII/357, LII/359.

Zbiory i zakupy 1935, sygn. L/189c.

Archiwum Narodowe w Krakowie

Akta Miasta Krakowa, sygn. 29/33/5.6.4/SMKr 450, s. 433; sygn. 29/33/5.6.4/SMKr 537, s. 417, 419, 429, 443; sygn. 29/33/5.6.6/SMKr 772, poz. 1451-1457, 1459

Akta poniemieckie, Dane osobowe Żydów ze zdjęciami w układzie wg numerów Kennkart (numery: 8689-8900), sygn. 29/1576/28, poz. 8860, 8863, 8864, 8866.

Spis ludności miasta Krakowa z r. 1921, sygn. 29/91/14, s. 462, poz. 6704, 6705.

Urząd Zdrowia w Krakowie, Księga urodzin Chrześcijan i Izraelitów z 1936 r., t. 1, sygn. 29/83/8/412, poz. 3511.

Centralna Biblioteka Judaistyczna ŻIH w Warszawie

Ankiety personalne osób skierowanych do wysiedlenia z Krakowa, sygn. 218/34/176/61. 


\section{Opracowania}

Grądzka-Rejak Martyna: Nikt nie wierzy w petna zagładę. Akcja „Reinhard” w okupowanym Krakowie. „Biuletyn IPN” 2017, nr 6 (139), s. 21-31.

Kravtsov Sergey, Levin Vladimir: Synagogues in Ukraine, t. 1-2. Jerusalem: The Center for Jewish Art, The Hebrew University of Jerusalem, and the Zalman Shazar Center, 2017.

Księga Pamięci. Transporty Polaków do KL Auschwitz z Krakowa i innych miejscowości Polski potudniowej 1940-1944, t. 1-4. Red. Franciszek Piper, Irena Strzelecka. Kraków: Muzeum i Towarzystwo Opieki nad Oświęcimiem, 2002.

Lebet-Minakowska Anna: Katalog judaików. Cz. 1: Tkaniny. Kraków: Narodowe Centrum Kultury, 2008.

Lebet-Minakowska Anna: Parochet - dar „Pobożnej Pani Sary” - jako przykład przekazu symbolicznego. W: Żydzi Wschodniej Polski. Seria 5. W kreggu judaizmu. Red. Jarosław Ławski i Iwona E. Rusek. Białystok: Wydawnictwo Prymat, Mariusz Śliwowski, 2017, s. $165-199$.

Musioł Teodor: Dachau 1933-1945. Opole: Śląsk, 1971.

Piechotkowie Maria i Kazimierz: Bramy nieba. Bożnice murowane na ziemiach dawnej Rzeczypospolitej. Warszawa: Krupski i S-ka, 1999.

Słownik geograficzny Królestwa Polskiego i innych krajów słowiańskich, t. 9. Red. Filip Sulimierski, Bronisław Chlebowski, Władysław Walewski. Warszawa: nakładem Władysława Walewskiego, 1888.

Supranowicz Elżbieta: Nazwy ulic Krakowa. Kraków: Polska Akademia Nauk, 1995.

\section{Wydawnictwa elektroniczne}

Miejsce Pamięci i Muzeum Auschwitz-Birkenau, Informacja o więźniach, http://auschwitz. org/muzeum/informacja-o-wiezniach/ (odczyt: 02.11.2018).

Smajdor Michał, Wykaz zmian nazw alei, mostów, osiedli, parków, placów, rond i ulic w Krakowie, http://www.kmk.krakow.pl/artykul_nazwy_ulic.html (odczyt: 02.11.2018).

Yad Vashem the World Holocaust Remembrance Center, The Central Database of Shoah Victims'Names, https://yvng.yadvashem.org/nameDetails.html?language=en\&itemId $=\ldots \&$ ind $=1$ [w miejsce kropek podać należy wartość itemId podaną $\mathrm{w}$ tekście; w artykule wykorzystano rekordy o itemId: 418075, 513568, 513659, 514555, 741217, 870026, 8749991, 8750025, 10407719, 10407917, 10408038, 10408056, 10408088, 10408124, 10408146] (odczyt: 02.11.2018).

\section{PODSUMOWANIE Szymon Rabinowicz - odnaleziony}

Muzeum Narodowe w Krakowie w latach 1935-1939 rozpoczęło kolekcjonowanie rzemiosła żydowskiego w celu utworzenia „działu judaików”. W antykwariatach i u osób prywatnych kupowano wycofane z kultu i użycia judaika reprezentujące wszystkie dziedziny życia. Znaczna ich część trafiła do zbiorów muzealnych zakupiona za pośrednictwem 
mieszkającego w Krakowie-Podgórzu Szymona Rabinowicza, handlarza starzyzną. Choć przyczynił się do zakupu do Muzeum Narodowego w Krakowie wielu cennych obiektów, pozostawał osobą anonimową, skąd pochodził, gdzie mieszkał, czym się zajmował, kiedy i gdzie zmarł. Wśród pracowników muzeum mnożyły się hipotezy. Po wielu latach archiwalnych poszukiwań udało się ustalić, że pochodził z miejscowości Frysztak koło Strzyżowa, urodził się 16 grudnia 1895 r. Do Podgórza przybył w 1914 r. (lub 1917) i tu osiadł na stałe. W latach 1914-1917 służył w armii austriackiej na froncie rosyjskim, zginął w krakowskim getcie lub transporcie z obozu w Płaszowie do Treblinki w 1942 r. Zawodowo zajmował się handlem starzyzną.

\section{SUMMARY \\ Szymon Rabinowicz - rediscovered}

In 1935, the National Museum in Krakow began collecting Jewish handicraft with the aim of establishing the "Judaica department". Until WWII (1939), numerous objects were purchased with the help of antique shops and private individuals. One of the main sources (or even the most important) was Szymon Rabinowicz, a Jewish antique dealer. Surprisingly, although his work was very important for the preservation of Jewish culture, very little was known about him - he was virtually anonymous. Even worse: many legends about him that were spread among old curators of the Museum turned out to be completely untrue. It was only about 75 years after his death that it became possible to reconstruct his life. Now we know that he was born in Frysztak (near Strzyżów, Poland) on 16 December 1895. He arrived in Podgórze in 1914 or 1917 and settled there. During WWI (1914-1917), he served in the Austro-Hungarian army on the Russian front, but was killed by the Germans either in the Krakow Ghetto or during the transport from KL Plaszow to the Death Camp in Treblinka, in 1942.

SŁOWA KLUCZOWE: kolekcjonerstwo, judaika, Muzeum Narodowe w Krakowie, Szymon Rabinowicz, getto, II wojna światowa

KEY WORDS: collectability, Judaica, National Museum in Krakow, Szymon Rabinowicz, ghetto, World War II 